\title{
DZIEJE PATRYSTYKI W ŚRODOWISKU KRAKOWSKIM
} (Zarys)

Jaki jest nasz bilans na tym polu? Tak jak i w innych dziedzinach niezbadany. Chciałbym, aby moje wystąpienie było małym przyczynkiem ilustrującym wkład środowiska krakowskiego do patrologii polskiej. Na wstępie zaznaczam, że nie będę zajmował się działalnością patrystyczną księży jezuitów działających także w tym środowisku, bo jest temu poświęcony osobny referat ks. dra Stanisława Łucarza SJ. Podzielę swoje wystąpienie na 4 główne etapy. Pierwszy to zainteresowanie na Akademii Krakowskiej Ojcami Kościola w dobie renesansu, następnie chciałbym naszkicować badania homiletyczno-pastoralne podjęte nad spuścizną Ojców w XIX wieku, by przejść do prób nadania studiom patrystycznym w Krakowie jasnych ram naukowych, aż po utworzenie pierwszej polskiej Katedry Patrologii na Uniwersytecie Jagiellońskim. Wreszcie omówię działalność środowiska krakowskiego rozpoczętą przez ks. profesora Mariana Michalskiego, a dziś związaną z działalnością Katedry Patrologii i Historii Dogmatu na Papieskiej Akademii Teologicznej w Krakowie.

1. Akademia Krakowska. Początki zainteresowania Ojcami Kościoła w aspekcie duszpasterskim w Krakowie można połączyć z osobą świętej królowej Jadwigi. To na jej zamówienie powstaje Modlitewnik Jadwigi, który w $50 \%$ stanowi pierwszą antologię literatury patrystycznej powstałą w naszym kraju. Sam modlitewnik ${ }^{1}$ liczy ponad 200 kart, pisanych przez kilka osób i zawiera fragmenty z dzieł, m.in. Jana Chryzostoma czy Grzegorza Wielkiego. W przededniu polskiego Renesansu w Krakowie spowiednik Jadwigi, ojciec dominikanin, wybiera na lekturę dla władczyni i jej dworu zestaw tekstów Ojców. Zapowiada to przyszłość. Modlitewnik do dziś przechowywany w Archiwum Kapituły Metropolitalnej na Wawelu jest piękną pamiątką nie tylko z naszej historii, ale i świadectwem rodzącego się zainteresowania myślą teo-

${ }^{1}$ Por. nr 69 wg katalogu I. Polkowskiego, Archiwum Krakowskiej Kapituły Metropolitalnej na Wawelu, Kraków 1884. 
logiczną Ojców Kościoła. Pierwszą natomiast pozycją Ojców Kościoła wydaną drukiem w Polsce jest De doctrina christiana św. Augustyna z 1475 roku $^{2}$.

2. Dalszy etap - to czas polskiego Renesansu. Tu jednak zainteresowania środowiska krakowskiego, wspartego przez biskupa Tomickiego hojnym mecenatem biskupów krakowskich, koncentrują się bardziej na filologicznej stronie zagadnienia. To w Krakowie drukuje swoje wydania św. Ambrożego Erazm z Rotterdamu dedykując je prymasowi Łaskiemu ${ }^{3}$. Również Stanisław Hozjusz jako młody sekretarz króla publikuje Commonitorium Wincentego z Lerynu ${ }^{4}$. To właśnie biskup warmiński Hozjusz opierając się w przyszłości na św. Augustynie stanie się jednym z filarów reformy trydenckiej i nie wierząc w skuteczność scholastyki będzie szukał swych rationes $w$ dysputach z protestantami ${ }^{5}$ w druku patrystycznych pozycji ${ }^{6}$. Zaczęło się to jednak już wcześniej, od pamiętnego roku 1528, który można nazwać początkiem polskiej patrystyki, kiedy to grecysta i mistrz Jerzy Liban z Lignicy przygotował z polecenia kanclerza Uniwersytetu Jagiellońskiego bpa Piotra Tomickiego opatrzoną komentarzem antologię pism trzech greckich Ojców Kościoła: Bazylego, Grzegorza z Nazjanzu i Jana Chryzostoma ${ }^{7}$. Była to pierwsza sporządzona przez Polaka,

${ }^{2}$ Por. J. Dyl, „Omnes libri beati Augustini Aurelii: De doctrina christiana tres, praeter quartum qui tractat de modo pronuntiandi sermones katholicos”. Pierwsza ksiązka patrystyczna wydrukowana w Polsce, VoxP 8(1988) t. 15, 803-809.

${ }^{3}$ Związki Erazma z Rotterdamu z Polską poprzez episkopat są bardzo silne. Jest to nie tylko dar dla prymasa Łaskiego, ale i: 1. korespondencja z biskupem Tomickim, dar 60 dukatów, dedykacja biskupowi nowego wydania Seneki (Bazylea 1529); 2. Stanisław Hozjusz i jego korespondencja via Jan Łaski; 3. korespondencja z biskupem Andrzejem Krzyckim; 4. biskupowi Janowi Dantyszkowi dedykuje Erazm 1 tom $O$ Duchu Świętym św. Bazylego.

${ }^{4}$ Zgodnie z danymi jego sekretarza Reszki. Bez wątpienia, wydanie jest przygotowane (na podstawie edycji Jana Sicharda z Bazylei) w 1538 roku, a w gronie biskupa chełmskiego Samuela Małachowskiego jest tylko jeden duchowny - teolog, który mógł się tego podjąć - Stanisław Hozjusz, por. J.N. Fijałek, Przekłady pism św. Grzegorza z Nazyanzu w Polsce, Kraków RWFPAU 1918, z. 2, s. 92.

${ }^{5}$ W samym Krakowie próba oparcia wykładu na Ojcach Kościoła przez Mateusza z Kościana (spowiednika i powiernika biskupa Piotra Gamrata) spotkała się z ostracyzmem i odrzuceniem przez pozostałych profesorów Akademii. Jego novum to wykład w oparciu o Pismo Święte i egzegezę Ojców bez scholastyki.

${ }^{6}$ Jest to oficjalna tendencja polskiego episkopatu, który dwukrotnie na synodach prowincjalnych (pierwszy lęczycki prymasa Jana Łaskiego - 3 lipca 1527 r. i drugi piotrkowski prymasa i biskupa krakowskiego Piotra Gamrata 17 X 1542 r.) nakazał kapłanom pracującym w duszpasterstwie obok Pisma Świętego Nowego i Starego Testamentu posiadać dzieła św. Ambrożego, św. Atanazego, św. Jana Chryzostoma, św. Bazylego, św. Hilarego, św. Hieronima, św. Leona papieża, św. Grzegorza papieża, św. Grzegorza z Nazjanzu; ten drugi zachęcał nawet do lektury Orygenesa!, por. B. Ulanowski, Materyaty do historyi ustawodastwa synodalnego w Polsce w XVI w., AKP AU w Krakowie, t. 1, s. 366(3) i 389(3).

${ }^{7}$ Antologia ta pozostała jednak tylko w rękopisie, a informacja o niej w Katalogu rękopisów Biblioteki Załuskich w Warszawie: Specimen catal. codd. mss. Bibl. Zal., Dresdae MDCCLII 
i to pochodzącego ze środowiska krakowskiego, grecka antologia patrystyczna, której jednak szczegółowej zawartości i struktury nie znamy. Trzeba tu również wspomnieć dwa nieco wcześniej sporządzone przez Polaków kodeksy Biblioteki Jagiellońskiej (nr 1347 i 1406): sporządzony w 1446 r. dla jakiegoś duchownego (pro magistro Reverendo) przez profesora teologii i kaznodzieję katedry krakowskiej, a później rektora Akademii Krakowskiej Jana ze Słupcy kodeks 1347, zawierający na początku (s. 1-85) 8 mów Grzegorza z Nazjanzu w łacińskim przekładzie Rufina ${ }^{8}$, oraz przygotowany w 1448 r. na dworze kardynała Zbigniewa Oleśnickiego w Krakowie przez mistrza dra teologii Jana Dąbrówkę kodeks 1406, który obok mów Jana Damasceńskiego w drugiej części (s. 343-623) zawiera opatrzone niewielkim komentarzem mowy Grzegorza z Nazjanzu także w przekładzie Rufina. Inni nieco późniejsi autorzy - humaniści nie tyle już sięgają do oryginałów, co starają się osiągnięcia zachodnich badaczy udostępnić w Polsce. Należą do nich m.in.: filozof i grecysta (vir graecarum litterarum peritissimus) Akademii Krakowskiej Stanisław Grzepski $^{9}$, grecysta tejże Akademii Jan Nowak z Dysa pod Lublinem ${ }^{10}$, tłumacz pism Grzegorza z Nazjanzu i apologety Justyna Jan Lang ", pierwszy thumacz na język polski pism św. Justyna Wawrzon Krzyszkowski ${ }^{12}$ i wydawca pism św. Jana Chryzostoma Jan Kochleusz ${ }^{13}$.

117-118, 119, nr CCCXCVI; zob. S. Longosz, Święty Grzegorz z Nazjanzu w Polsce, VoxP 10(1990) z. $19,988-89$.

${ }^{8}$ Por. C. Moreschini, Rufino traduttore di Gregorio Nazianzeno, „Antichità altoadriatiche” 31(1987) 227-285.

${ }^{9}$ Pochodzący z Płocka Stanisław Grzepski przedrukowuje w 1565 r. w Krakowie z bazylejskiego wydania (r. 1550), opatruje niewielkim łacińskim komentarzem i dedykuje kardynałowi Hozjuszowi Duo poemata Gregorii Nazianzeni (Carmina I. II 9: De virtute i I. II 16: De vitae itineribus, PG 37, 667-680 i 777-781, BJ Cim. 0. 301 i 302) oraz przekłada poetycko na język polski i dedykuje wraz z tekstem greckim krakowskiemu lekarzowi - humaniście Antoniemu Sznebergierowi wiersz De naturae humanae fragilitate (Carmen I. II 13, PG 37, 754-756, przedruk polskiego przekładu - Fijałek s. 192-193.

${ }^{10}$ Pochodzący z Dysa, uczeń Stanisława Grzepskiego, Jan Nowak przełożył na łacinę opracowany na Węgrzech zbiór sentencji gregoriańskich pt. Sententiae et regulae vitae ex Gregorii Nazianzeni scriptis collectae per Joannem Sambucum Pannonium, interpretete M. Joanne Novacio de Dys (Cracoviae 1578. BJ Cim. Qu. 4453) i dedykował go (bez odpowiedzi) biskupowi kujawskiemu Stanisławowi Karnkowskiemu (1520-1603) z prośbą o poparcie swoich studiów patrystycznych.

11 Pochodzący ze Śląska Cieszyńskiego, kanclerz biskupów wrocławskich, później poseł Habsburgów wydaje w 1561 roku pierwsze tłumaczenie (na łacinę) dzieł św. Grzegorza z Nazjanzu w Polsce, a w 1565 r. pism Justyna; por. Graeca quaedam et sancta carmina. Cum latina Joannis Langi Silesii interpretatione, Basileae 1561, Io. Oporinus, s. 240; Operum quae extant omnium per Ioannem Langum Silesium e graeco in latinum sermonem versorum et sententiis priscorum sanctorum Patrum illustratorum tomi III, Basileae 1565, per Ambrosium et Aurelium Frobenios fratres; por. J. Czerniatowicz - Cz. Mazur, Recepcja antyku chrześcijańskiego w Polsce. Materiaty bibliograficzne, t. I: wiek XV-XVIII, cz. I: Autorzy, Lublin 1978, s. $50 \mathrm{nr} 304$ i s. $71 \mathrm{nr} 458$.

12 Por. Rozmowa z Tryfonem Żydem do Marka Pompeiusa napisana, w której się zamyka nauka o prawdziwym poznaniu jednego Boga, która nie tylko żydowski ale i Sabeliantów starych 
3. Wiek XVII i XVIII - to wyraźny regres. Poza jednym tłumaczem zarówno dzieł Ojców, jak i współczesnych sobie opracowań zachodnich - ks. Sebastianem Piskorskim nie mamy praktycznie nic ${ }^{14}$. Początek zmian to wizytacja sołtykowska Akademii Krakowskiej pod koniec XVIII wieku i idąca za nią reforma kołłątajowska, kiedy to w wykładach historii Kościoła zaczęto podkreślać znaczenie dorobku Ojców Kościoła, a w formie dodatku wykładać elementy patrystyki. Od tej pory przez prawie cały wiek XIX - do działalności Wydziału Filologicznego UJ jak i sekcji filologicznej PAU w Krakowie - wykłady z patrystyki stały się częścią wykładów z historii Kościoła, a ich poziom i zakres zależał od profesora przedmiotu.

4. Wiek XIX. Duży wpływ na ustalenie się zasady konieczności dostępu studentów teologii do spuścizny patrystycznej ma józefinizm. To jego tezy w połączeniu z zaproponowanym wykładem teologii pastoralnej w ujęciu czysto praktycznym i utylitarystycznym doprowadzają do coraz szerszego zainteresowania tą dyscypliną. $\mathrm{Z}$ tego czasu trzeba tu wspomnieć przynajmniej dwóch profesorów: K. Teligę, który wykładał historię Kościoła według Klei$\mathrm{na}^{15}$ i P.F. Pękalskiego (omnipotens - przeszedł przez prawie wszystkie katedry Wydziału Teologicznego Uniwersytetu, będąc ostatnim miechowitą w Polsce przed restauracją tego zakonu w naszych czasach) ${ }^{16}$. Wybitną postacią był też

i dzisiejszych błąd wywraca. K tej rozmowie przydan jest List krótki tegoż Justyna do dwu braciej, Nieśwież 1564, Druk. Danielowa [podpisany Laurentius Criscovius], zob. Czerniatowicz-Mazur s. $71 \mathrm{nr} 459$.

${ }^{13}$ Kasztelan krakowski i kanonik wroclawski Jan Kochleusz [Cochlaeus] wykorzystał tu „niecnie” pracę Marcina Kromera z Biecza. Ten ostatni, znalazłszy w Bolonii w zniszczonym przez robaki rękopisie eklogi homiletyczne św. Jana Chryzostoma wydał je z opracowaniem i thumaczeniem na łacinę w Krakowie w 1541 roku. Korespondencja obu zachowała się. Kochleusz zaś: Orationes octo ex antiquo exemplari graeco in latinum versae et aliis eius homeliis et operibus non adiunctae, Martino Cromero interprete denuo aditae (1. De non contemnenda Ecclesia Dei et divinis mysteriis. 2. De divitiis et paupertate. 3. De ingluvie et ebrietate. 4. De adversa valetudine. 5 . De anima. 6. De humilitate. 7. De avaritia. 8. De uxore et pulchritudine), Moguntiae 1550, F. Behem [Ded. Ioanni comiti Tarnovio, castell. crac. Ioanneus Cochlaeus, canonicus Vratislaviensis], por. Czerniatowicz - Mazur s. 54 nr 331.

${ }^{14}$ Por. Żywoty Ojców abo dzieje $i$ duchowne powieści starców, zakonników, pustelników wschodnich. Przez św. Hieronima i inszych pisane. Staraniem i nakładem Katarzyny z Sobieszyna ks. Radziwiltowej podkanclerzyny i hetmanowej WXLit. od X.M. Sebastiana Jana Piskorskiego, Akad Krak. profesora na polski język przettumaczone i do druku podane, Kraków 1688, Druk. Akad, ss. 862 [Zbiór zawiera m.in. Historię mnichów egipskich Rufina, Historię Lauzjacką Palladiusza, Łąę duchowną Jana Moschosa, Historię życia zakonnego Teodoreta z Cyru); zob. A. Bober, Studia i teksty patrystyczne, Kraków 1967, s. 192; Czerniatowicz - Mazur s. 86 nr 532.

${ }_{15}$ Por. ks. K. Teliga (1808-1884), prałat kapituły katedralnej, trzykrotny rektor Akademii Krakowskiej, autor m.in.: O przedmiocie, wtaściwościach, celu $i$ wptywie historii kościelnej na inne umiejętności, „Rocznik Tow. Nauk. z Uniw. Krak. Połączonego” 27(1843) 42-62.

${ }^{16}$ Por. ks. Piotr Franciszek Pękalski (1790-1874), bożogrobiec, przełożył Wyznania św. Augustyna (Kraków 1847). 
w tym czasie pełniący obowiązki wykładowcy przeor dominikanów o. Mateusz Kozłowski, zmarły w 1839 roku. Obok własnych zainteresowań patrystycznych przełożył też i wydał między innymi Mowy Teodoreta z Cyru ${ }^{17}$ oraz wprowadził w ramach swoich wykładów z historii Kościoła patrologię z elementami historii dogmatów. Traktował on swoją dyscyplinę raczej jako przygotowanie do teologii i dlatego starał się przygotować studentów do studiów historycznych, gdyż uważał metodę historyczną za najwłaściwszą w studium teologii.

Znakiem tendencji oparcia wykładów dogmatyki na studiach historycznych jest też pierwsza habilitacja na Wydziale Teologicznym UJ ks. J. Droździewicza w 1867 roku $^{18}$. Jej autor, proboszcz parafii św. Mikołaja w Krakowie i kanonik prezenty uniwersyteckiej, podejmuje wykłady z patrologii i kontynuuje je bez przerwy aż do 1881 roku. Niestety, po jego odejściu nikt już nie podjął zagadnienia i powrócono do wykładania patrologii w ramach historii Kościoła lub innych dyscyplin: dogmatyki, teologii fundamentalnej lub homiletyki. W tym momencie należy wspomnieć bł. Józefa Sebastiana Pelczara, wykładowcę najpierw historii Kościoła, a później teologii pastoralnej. Jest on bowiem twórcą jedynego na razie w Polsce podręcznika historii kaznodziejstwa, gdzie w I tomie wiele miejsca poświęcił spuściźnie patrystycznej ${ }^{19}$.

Odrodzenie krakowskich studiów patrystycznych nie jest jednak związane z Wydziałem Teologicznym, a nawet w pierwszym okresie nie z zainteresowaniem kręgów kościelnych. Początek odrodzenia jest związany z działalnością profesora Kazimierza Morawskiego, wybitnego krakowskiego filologa o międzynarodowej sławie. Już w 1878 r. opublikował w „Przeglądzie Polskim” rozprawę: Chrześcijaństwo i patrycjat rzymski ${ }^{20}$, a pod patronatem Akademii Umiejętności omówił pisarzy rzymskich III i IV wieku ${ }^{21}$. Jego Historia literatury rzymskiej kończy się na tomie VII, na pisarzach III wieku, ale uwzględnia także pisarzy chrześcijańskich ${ }^{22}$. Z kolei jego Zarys literatury rzymskiej obszernie omawia pisarzy starochrześcijańskich, których traktuje jako spadkobierców

${ }^{17}$ Por. O.M. Kozłowski (1759-1839) przełożył m.in. z języka greckiego, zachowaną jedynie w rękopisie Mowę o Opatrzności Teodoreta z Cyru.

18 Por. ks. Jan Droździewicz (1812-1888) w r. 1867 został docentem prywatnym patrologii po napisaniu rozprawy habilitacyjnej pt. De utilitate et necessitate legendi SS. Patrum. Jest też autorem: De primatu Pontificis Romani. Dissertatio theologica, Cracoviae 1884, Typ. Universitatis.

${ }^{19}$ Por. J.S. Pelczar (1842-1924), Zarys dziejów kaznodziejstwa w Kościele katolickim, t. 1: Kaznodzieje greccy do IX wieku i łacińscy do XVI wieku, wyd. 2, Kraków 1903.

${ }^{20}$ Por. K. Morawski, Chrześcijaństwo i patrycjat rzymski, ,Przegląd Polski” 12(1887-1888) z. 3, 358-381.

${ }^{21}$ Por. De scriptoribus Romanis III et IV post Christum natum saeculi observationes (De Arnobio, Lactantio, Ammiano Marcellino, Claudiano), Cracoviae 1921, PAU Wydz. Filologoczny. Rozprawy 60,2.

22 Por. Historia literatury rzymskiej, t. 7: Schytek literatury rzymskiej w drugim i trzecim wieku po Chrystusie, Kraków 1921 ss. 72-132 (Początki literatury chrześcijańskiej, Tertullianus, Minucius Felix, Caecilius Cyprianus, Novatianus), ss. 159-181 (Arnobius, Lactantius). 
$\mathrm{Rzymu}^{23}$. Dzieło to podejmuje jego uczeń i współpracownik prof. Adam Stefan Miodoński, który również wiele swoich prac poświęcił badaniom antyku

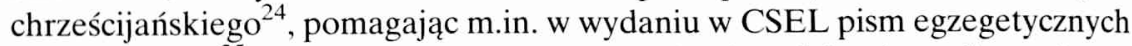
św. Augustyna ${ }^{25}$. Równolegle prof. Leon Sternbach podejmuje studia z zakresu literatury bizantyjskiej ${ }^{26}$ oraz publikuje od 1891 r. nie wydane wcześniej poematy Jerzego z Pizydii ${ }^{27} \mathrm{i}$ inne materiały patrystyczne, zwłaszcza dotyczące św. Grzegorza z Nazjanzu ${ }^{28}$.

5. Próba wydania dzieł Grzegorza z Nazjanzu. Osobny rozdział to podjęcie w 1905 roku przez PAU za namową Ulricha von Wilamowitza - Moellendorffa projektu opracowania i wydania krytycznego dzieł Grzegorza z Nazjanzu. Prace miał koordynować profesor Leon Sternbach. Podjęto pierwsze badania

${ }^{23}$ Por. Zarys literatury rzymskiej, Kraków 1922, ss. 288-300 (Początki literatury chrześcijańskiej. Tertulian, Minucius Felix, św. Cyprian, Arnobius, Lactantius), ss. 322-363 (Proza w chrześcijańskim piśmiennictwie, Hilarius z Poitiers, św. Ambroży, św. Hieronim, św. Augustyn, Sulpicius Severus, Orosius, Aetheria), ss. 375-390 (Poezja chrześcijan, Laudes Domini i centon Proby, Juvencus, Damasus, św. Ambroży, Prudentius, Paulinus), ss. 397-408 (Późniejsza poezja i proza chrześcijańska.).

${ }^{24}$ Por. Z dziejów Kościoła rzymskiego pierwszych trzech wieków, „Przegląd Polski” 27(1893) t. 108, 336-345; O świadectwie duszy Tertuliana, „Eos” 10(1904) 117-121; Grzegorz Nysseński o ciśnieniu ciepta stonecznego, „Eos” 11(1905) 161-168; „Quo vadis” Sienkiewicza i Minutiusa Feliksa, PP 21/1904, t. 82, 346-370; Anonymus „Adversus aleatores”. Kritisch verbessert, erläutert und ins Deutsche übersetzt von Dr. Phil. Adam Miodoński, Erlangen Leipzig 1889; Zur Kritik der ältesten lateinischen Predigt de aleatoribus, w: Commentationes Wölfflin, Freiburg 1891, 371-376; Incerti auctoris „Exhortatio de poenitentia”. Ope codicis Parisini nr 550, PAU Wydz. Filolog. Rozprawy II 20, Cracoviae 1892, 125-134; O apologii chrześcijańskiej senatora Apoloniusza. Żółkiew 1897; De ortu et obitu Patrum (wydanie krytyczne z PL 83, 129-156), w: Analecta graeco-latina philologis Vindobonae congregatis obtulerunt collegae Cracovienses et Leopolitani, Cracoviae 1893, 18-29; zob. T. Sinko, Adam Stefan Miodoński. Wspomnienie pośmiertne, „Eos” 19(1913) 113-125; J.M. Szymusiak, Zarys dziejów patrystyki, w: Dzieje teologii katolickiej w Polsce, III cz. 1: Wiek XIX i XX, Lublin 1976, 86-87.

25 Zbiera rękopisy i opracowuje je podczas swego dwuletniego pobytu (18891890) we Włoszech.

${ }^{26}$ Por. m.in. Analecta Byzantina, „Česke Museum Filologické” 6(1900) 291-322; Analecta Photiana, w: PAU Wydz. Filolog. Rozprawy II 5, Cracoviae 1894, 83-124.

${ }_{27}$ Por. De Gregorio Pisida apud Theophanem aliosque historicos reliquiis, PAU Wydz. Filo$\log$ Rozprawy II 15, Cracoviae 1900, 1-107; De Georgii Pisidae fragmentis a suida servatis, tamże 108-198; Observationes de Georgii Pisidae carmina historica, tamże 199-296; Analecta Avarica, tamże 297-365; De Georgii Pisida Nonni sectatore, w: Analecta graeco latina, dz. cyt. 38-54; Studia philologica in Georgium Pisidam, Cracoviae 1900.

${ }_{28}$ Por. Der Gregorio Nazianzeno Homeri interprete, w: Stromata in honorem Casimiri Morawski, Cracoviae 1908, 171-178; Dilucidationes Nazianzenicae, cz. 1-2, „Eos” 16(1910) 11-25 i 17(1911) 36-44; Glossarium Parisinum in Gregorii Nazianzeni carmina, w: PAU Sprawozdania 14. Cracoviae 1909; Quaestiones prosopographicae de S. Olympiade, Sprawozdania 15, Cracoviae 1910; Wptywy aleksandryjskie i poaleksandryjskie u Grzegorza z Nazjanzu, PAU Sprawozdania 27, Cracoviae 1922; Prolegomena in Carmina Gregorii Nazianzeni, PAU Sprawozdania 30, Cracoviae 1925. 
i kwerendę. I tak, profesor historii Kościoła J. Fijałek przygotował kwerendę dotyczącą wydań pism św. Grzegorza w Polsce ${ }^{29}$, profesor Gustaw Przychocki zajął się opracowaniem Listów Grzegorza ${ }^{30}$, które były tematem jego rozprawy habilitacyjnej (1912). I choć praca jego była gotowa w momencie habilitacji, to jednak autor - jak sam pisze - z przyczyn od niego niezależnych utracił możliwość korzystania z materiałów - i Historia listów ukazała się dopiero w 1946 roku $^{31}$. Wydanie krytyczne listów - nie bez wykorzystania jego badań - ukazało się później w serii „Belles Lettres” w Paryżu w opracowaniu P. Gallaya ${ }^{32}$. Z G. Przychockim współpracował prof. Jan Sajdak ${ }^{33}$, który na posiedzeniu Kółka Filologicznego Studentów UJ w ramach 50-lecia zapowiadał 17 V 1930 r. wydanie w Krakowie przez ,naszą szkołę filologiczno-patrystyczną" Mów przez T. Sinkę, Poematów przez L. Sternbacha, Listów przez St. Witkowskiego. Niestety, zamierzenia te nie zostały uwieńczone sukcesem. Wspomniany uczestnik tych prac, dr T. Sinko w latach 1906-1928 opublikował kilkanaście pozycji związanych z tym projektem ${ }^{34}$. Czy to dużo? Bibliografia prac T. Sinki opracowana pod jego nadzorem wymienia 741 pozycji ${ }^{35}$. Z nich

${ }^{29}$ Por. J. Fijałek, Przekłady pism św. Grzegorza z Nazjanzu w Polsce, „Polonia Sacra” 1(1918) 46-144, 3(1919) 126-207.

${ }^{30}$ Por. Historia listów św. Grzegorza z Nazjanzu, Kraków 1946; zob. inne: De Gregorii Nazianzeni Epistolarum codicibus Britanicis, PAU Wydz. Filolog. Rozprawy 50, Cracoviae 1912, 230-246; De Gregorii Nazianzeni Epistularum codicibus Laurentianis, ,Wiener Studien” 33(191) 251-263; Watykańskie rękopisy Listów św. Grzegorza z Nazjanzu, „Eos” 16(1910) 100-135.

${ }^{31}$ W 1912 r. ks. Jan Fijałek obejmuje katedrę historii Kościoła, a jednym z pól jego działalności jest wydanie dzieł św. Grzegorza z Nazjanzu, słynął on jednak z dość konfliktowego charakteru (zob. np. jego propozycję redukcji Wydziału Teologicznego UJ z 1918 roku).

${ }^{32}$ Por. S. Grégoire de Nazianze, Lettres, éd. P. Gallay, vol. 1-2, Paris 1964, Édition „Les Belles Lettres”; zob. też: S. Grégoire de Nazianze, Lettres théologiques, éd. P. Gallay, SCh 208, Paris 1974.

33 Związany ze środowiskiem poznańskim prof. J. Sajdak i jego monumentalna publikacja: Historia critica scholiastarum et commentatorum Gregorii Nazianzeni. Accedit Appendix de pseudo-Gregorianis et Gregorii encomiis oraz Zarys literatury bizantyńskiej są omówione niżej przez ks. B. Czyżewskiego.

34 Por. Studia Nazianzenica RWFPAU 41(1906) 249-312 i SPAU 12(1907) nr 5; De Nicephoro Xanthopoulo Gregorii Nazianzeni imitatore, „Eos”12 (1906) 91-97; O rękopisach mów św. Grzegorza z Nazjanzu w bibliotekach wtoskich, tamże 98-107 i 15(1909) 63-81; O rękopisach mów Grzegorza z Nazjanzu w paryskiej Bibliothéque Nationale, „Eos” 12(1906) 21-26; De Gregorii Nazianzeni laudibus Macchabaeorum, „Eos” 13(1907) 1-29; De Cypriano martyre a Gregorio Nazianzeno laudato, RWFPAU 53(1961) 318-347; De traditione orationum Gregorii Nazianzeni, cz. 1-2, Kraków 1917 i 1923; Liryka św. Grzegorza z Nazjanzu, „Polonia Sacra” 1(1918) 29-45; $Z$ historii studiów nazjanzeńskich w Polsce, „Nova Polonia Sacra” 1(1928) 313-332; De inventione, tempore, consilio librorum de sacerdotio Joannis Chrysostomi, Mélanges de H. Grégoire = „Annuaire de l'Institut de Philologie et d'Histoire Orientales et Slaves" 9(1949) 531-545 por. SPAU 50(1949) nr 8, 405-408; Chronologia poezji św. Grzegorza z Nazjanzu, SPAU 48(1947) nr 5, 147-156.

35 Por. W. Madyda, Bibliografia prac naukowych prof. dra Tadeusza Sinki, w: Charisteria Thaddaeo Sinko ab amicis collegis discipulis oblata, Varsaviae-Vratislaviae 1951, 1-31. 
dla patrologii najistotniejszy jest III tom Literatury greckiej ${ }^{36}$ i II tom Zarysu literatury greckiej ${ }^{37}$. Wprowadzając do swych wykładów Ojców Kościoła, analizując ich dzieła oraz działalność, dowartościował spuściznę chrześcijańską tamtych czasów i utorował drogę do samodzielnych studiów patrystycznych. Pod koniec życia publikuje w Wydawnictwie Mariackim wojenne przekłady pism św. Jana Chryzostoma. Niestety, zawirowania polityczne nie pozwoliły mu na ukończenie tego dzieła, z którego wydane zostały tylko trzy tomy ${ }^{38}$. Dziś, po upływie 50 lat opracowuje i wydaje resztę jego tłumaczeń Homilii do Corpus Paulinum ks. dr Arkadiusz Baron pracujący w ramach Katedry Patrologii i Historii Dogmatu na PAT w Krakowie.

6. Okres dwudziestolecia. Dalsze krakowskie studia nad Ojcami Kościoła związane były z Katedrą Historii Kościoła, przy której ks. W. Chotkowski wykładał w ramach swojego przedmiotu historię literatury kościelnej ${ }^{39}$, a jego uczeń i następca (po upływie 12 lat) ks. dr Jan Fijałek kontynuował te wykłady w latach 1920-1921. Szczególnie wkład tego ostatniego jest znaczący. W ramach swoich zainteresowań włączył się, jak już wspomniano, w przygotowanie edycji dzieł św. Grzegorza z Nazjanzu. Seminarium naukowe, które prowadził, było często głębokim pochyleniem się nad dziełami Ojców Kościoła. Tak na przykład w roku akademickim 1918/1919 prowadził Lekturę i przekład Listu do Diogneta, w latach 1925/1926 objaśnial Dawne i nowe przekłady polskich pism patrystycznych, a w roku 1928/1929 - Cześć $i$ dzieła św. Augustyna. Wreszcie, to on był tym, który zaproponował wysłanie na studia ks. M. Michalskiego, i choć ich współpraca po roku skończyła się gwałtownie, tym niemniej wpływ na formę wykładu ks. M. Michalskiego, prowadzenia seminariów, jak i zainteresowanie przekazem pozostał duży.

Kolejnym etapem w działalności środowiska krakowskiego było powołanie pierwszej w Polsce samodzielnej Katedry Patrologii i Historii Dogmatu. Starania o to trwały przez wiele lat. Po utworzeniu nowych diecezji częstochowskiej i śląskiej postanowiono otworzyć ich seminaria diecezjalne w Krakowie. Przy dużej życzliwości księcia A.S. Sapiehy zarówno biskup T. Kubina, jak i A. Hlond erygują i budują tutaj swoje seminaria w pobliżu Uniwersytetu,

36 Por. Literatura grecka, t. III 1-2, Kraków 1951 i 1954.

37 Por. Zarys historii literatury greckiej, t. II, Warszawa 1959.

38 Por. Św. Bazyli Wielki, Wybór homilij i kazań, tłum. i wstępem opatrzył T. Sinko, Kraków 1947; Św. Jan Złotousty, Dwadzieścia homilij i mów, tłum. i wstępem opatrzył T. Sinko, Kraków 1947; Św. Jan Złotousty, Homilie na listy pasterskie św. Pawła i na list do Filemona, tłum. i wstępem opatrzył T. Sinko, Kraków 1949.

${ }^{39}$ Por. W. Chotkowski, Patrologia czyli historia literatury chrześcijańskiej wedtug wykładów, wydał J. Fijałek, Kraków 1884; Nowo znaleziona „Nauka dwunastu Apostołów”, przełożył i objaśnił..., PP 2(1885) t. 5, 232-249, 371-384 oraz oddzielna odbitka (Kraków 1885); Testamentum Domini nostri Jesu Christi, przełożył..., PP 17(1900) t. 65, 157-183. 
a ich kleryków włączają do jego Wydziału Teologicznego. Stanowiło to podstawę dla ich próśb dotyczących erygowania nowych katedr na Wydziale Teologicznym. Argumenty były naukowe, historyczne, ale i praktyczne, jak na przykład, że dzięki takiemu połączeniu państwo już zaoszczędziło pieniędzy, stąd można to, co trzeba by było wydać na samodzielne studia, przekazać na rozbudowanie obecnych. Mimo że starania ich nie przynosiły owoców, to nie zrezygnowano. I tak, w roku 1929/1930 bp M. Godlewski, profesor Katedry Historii Kościoła powszechnego prowadził wykłady z patrologii w formie prelekcji $^{40}$. Tymczasem Rada Wydziału w 1933 r. postanowiła przemianować zawieszoną Katedrę Historii Sztuki na Katedrę Patrologii i Historii Dogmatu. W latach 19321934 podjęto wykłady z introdukcji do historii dogmatu w ramach Katedry Teologii Dogmatycznej i powierzono je ks. E. Florkowskie$\mathrm{mu}^{41}$.

W międzyczasie Ministerstwo zaaprobowało plan i 31 VIII 1934 r. powstała pierwsza w Polsce Katedra Patrologii i Historii Dogmatu, którą powierzono ks. M. Michalskiemu. Po nostryfikacji jego dyplomu doktorskiego z Uniwersytetu Gregoriańskiego, podjął pracę dydaktyczną ${ }^{42}$. Obok wykładów prowadził seminaria naukowe w liczbie 2 godzin tygodniowo, podczas których przeanalizował następujące tematy: Didache, Ambrozjaster, nauka św. Ambrożego w «De fide ad Gratianum», dokumenty życia monastycznego. Praca ta jednak została przerwana dwukrotnie. W latach 19391941 był więziony w obozach koncentracyjnych w Sachsenhausen i Dachau. Po wojnie uzyskał habilitację 10 VIII 1945 r. na podstawie rozprawy: Nauka chrystologiczna Ambrozjastra. Studium historyczno-dogmatyczne. Po likwidacji Wydziału Teologicznego na Uniwersytecie Jagiellońskim został profesorem ATK; zmarł w 1987 roku $^{43}$. Po jego wyjeździe do Warszawy wykłady z historii dogmatów i (przez pewien czas) z patrologii przejął habilitowany na tym Wydziale w 1948 roku ks. Eugeniusz Florkowski ${ }^{44}$, który już wcześniej prowadził działalność dydaktyczno - naukową w zakresie patrologii ${ }^{45}$. Po krótkim okresie zamieszania ks. E. Florkowski jako pierwszy dziekan Papieskiego Wydziału Teologicznego (do r. 1968) prze-

${ }^{40} \mathrm{Z}$ tej dziedziny napisał jedynie: Rzym i katakumby rzymskie, „Miesięcznik Katechetyczno Wychowawczy" 27(1938) 128-130.

${ }^{41}$ Ponieważ Ministerstwo odmówilo mu zatwierdzenia, mimo iż chciał wykładać bezpłatnie, Biskup przeniósł wykłady do seminarium.

${ }^{42} \mathrm{Na}$ kursie II przez trzy semestry po 2 godziny patrologii, a na kursie $\mathrm{V}$ po trzy godziny tygodniowo historii dogmatu.

43 Por. wspomnienie pośmiertne: Ks. E. Staniek, Ks. Marian Michalski (1900-1987), VoxP 7(1987) t. 12-13, 545-546.

${ }^{44}$ Rozprawą habilitacyjną była: Soteriologia Pelagiusza. Studium historyczno-dogmatyczne, Kraków 1949.

${ }^{45}$ Był promotorem doktoratów: ks. Szczepana Pieszczocha, ks. Wacława Eborowicza, ks. Andrzeja Bobera, ks. Sudusia. Z jego publikacji patrystycznych zob.: Matka Boża w nauce Ojców Kościoła, w: Gratia plena. Studia teologiczne o Bogurodzicy, red. B. Przybylski, Poznań 1965, 
kazał wykłady ks. M. Michalskiemu, a sam - ze szkodą dla patrologii - zajął się wykładami jedynie z teologii fundamentalnej, które prowadził aż do śmierci w $1989 \mathrm{roku}^{46}$. Ks. Marian Michalski nie zostawił po sobie zbyt wielu uczniów; doktoryzowało się u niego zaledwie 2 patrologów ks. Edward Staniek i ks. Emil Stanula CSsR. Dziełem ks. prof. M. Michalskiego było niewątpliwie ukierunkowanie studiów krakowskich w kierunku komentarzy patrystycznych do Corpus Paulinum, jak i przygotowanie Antologii Patrystycznej, w której obok samych tekstów autor w postaci krótkich wstępów udostępnil czytelnikowi w świetny sposób podstawowe zagadnienia związane z patrologią ${ }^{47}$.

7. Stan aktualny. Dalszy etap krakowskiej patrologii jest związany z funkcjonowaniem Katedry Patrologii i Historii Dogmatu w ramach najpierw Papieskiego Wydziału Teologicznego, a następnie Papieskiej Akademii Teologicznej. W roku 1972 po ciężkiej chorobie ks. prof. Michalski przekazał wykłady swemu doktorantowi ks. E. Stańkowi, który w 1974 r. po obronie doktoratu przejmuje kierownictwo Katedry, najpierw (od 1975 r.) jako kurator, a od habilitacji w 1984 r. jako jej kierownik. W tym okresie ks. E. Staniek był promotorem ponad 120 prac magisterskich i kilkunastu licencjackich. W latach 1986-1996 pełnił on również funkcję kierownika Katedry Homiletyki na Wydziale Teologicznym PAT w Krakowie i większość swego czasu poświęcał pracy przy organizacji Katedry Homiletyki oraz Studium retoryki i środowiska homiletycznego. To właśnie tłumaczy dysproporcję w ilości promocji doktorskich w tym czasie - na 2 z patrologii (ks. dr Kazimierz Panuś i piszący te słowa) przypadło 6 doktoratów $z$ homiletyki. W tym też czasie na Papieskim Wydziale Teologicznym habilituje się ks. Sz. Pieszczoch, a po 1981 r. już na Wydziale Teologicznym PAT ks. B. Częsz, ks. H. Pietras, ks. A. Żurek i ks. M. Starowieyski.

Adiunktem w naszej Katedrze jest ks. dr Arkadiusz Baron: studia uwieńczone doktoratem ukończył w Rzymie, a dziś prowadzi samodzielne wykłady i seminarium magisterskie. Jego działalność naukowa jest jednak związana przede wszystkim z miejscowymi seriami wydawniczymi. Jak już wspomniałem, przejął on wydanie tłumaczenia Tadeusza Sinki Homilii do Listów św. Pawła św. Jana Chryzostoma (ukazały się Homilie do Listu św. Pawła do Rzymian). Jest on także współredaktorem serii Myśl Teologiczna i Źródła

59-78; Zarys historii dogmatu chrystologicznego w epoce patrystycznej, w: Stużyć prawdzie i miłości, Częstochowa 1984, 58-92.

${ }^{46}$ Por. wspomnienie pośmiertne: ks. E. Staniek, Ks. Eugeniusz Florkowski (1902-1989), VoxP 9(1989) t. 16, 517-518.

47 Por. Antologia literatury patrystycznej, t. 1-2, Warszawa 1975 i 1982; Nauka chrystologiczna Pelagiusza, CT 17(1936) 143-164 oraz oddzielna nadbitka (Lwów 1936); Nauka teologiczna nieznanego autora „De physicis”, Kraków 1937; Problem autorstwa tzw. „Ambrozjastra” w świetle jego nauki chrystologicznej. Studium patrystyczne, Kraków 1948. 
Myśli Teologicznej. Pozostali pracownicy Katedry to piszący te słowa adiunkt prowadzący wykłady i seminarium magisterskie w ramach Katedry dla studentów Wydziału Historii Kościoła, oraz pan mgr lic. Tytus Górski, który służy wszystkim radą i pomocą udostępniając swój przebogaty księgozbiór z zakresu martyrologii i antyku chrześcijańskiego. Do tego należy dołączyć dorobek wszystkich instytutów mających umowę z Akademią jak i działalność samego środowiska rozwijającą się dziś w trzech miejscach. Obok Katedry funkcjonują bowiem studia benedyktyńskie nad źródłami monastycyzmu, działalność dydaktyczno-wychowawczą prowadzi ks. prof. dr hab. H. Pietras w oparciu o Wydział Filozoficzno-Pedagogiczny XX. Jezuitów i kierowane przez niego wydawnictwo WAM. Choć nie można porównać tego stanu do pierwszych lat $\mathrm{XX}$ wieku, to jednak nawiązuje się współpraca $\mathrm{z}$ krakowskimi filologami klasycznymi, z którymi środowisko nasze stara się regularnie spotykać. W spotkaniach tych biorą udział: ks. Edward Staniek, ks. Henryk Pietras SJ, ks. Arkadiusz Baron, ks. Adam Bandura CM, ks. Kazimierz Gurda, ks. Stanisław Łucarz SJ i ks. Jan Żelazny. Staramy się, aby te nasze wzajemne wymiany doświadczeń miały miejsce przynajmniej raz w miesiącu.

\section{BIBLIOGRAFIA:}

Ks. Jan Nepomucen Fijałek, Przekłady pism św. Grzegorza z Nazyanzu w Polsce, Kraków RWFPAU 1918, zeszyt 2-3.

Ks. Tadeusz Glemma, Ksiądz Profesor dr Jan Nepomucen Fijałek. Kapłan i uczony, Wlocławek 1936.

Ks. Tadeusz Glemma, Wydziat Teologiczny Uniwersytetu Jagiellońskiego w latach 1795- 1847, Kraków 1949.

Mieczysław Markowski, Dzieje Wydziału Teologii Uniwersytetu Krakowskiego w latach 1397-1525, Kraków 1996.

Ks. Stanisław Piech, Wydziat Teologiczny Uniwersytetu Jagiellońskiego w latach 1880-1950, Kraków 1996.

Gustaw Przychocki, Historia listów św. Grzegorza z Nazjanzu, RWFPAU, t 67, 3, Kraków 1946.

Jan Staszel, Jan Fijatek - kapłan i uczony. Dziatalność w ekspedycji rzymskiej PAU, RWFPAU, r. XXXIX (1994).

Ks. Stanisław Wysocki, Seminaryum zamkowe w Krakowie. Jego dzieje i ustrój, Lwów 1910.

Jan Maria Szymusiak, Zarys dziejów patrystyki, w: Dzieje Teologii Katolickiej w Polsce, red. M. Rechowicz, III 1, Lublin 1976.

Stownik Polskich Teologów Katolickich, red. H. Wyczawski OFM, Warszawa 1981. Z dziejów filologii klasycznej na UJ, red. W. Madyda, Kraków 1964. 


\section{LA STORIA DELLA PATROLOGIA NELL'AMBIENTE DI CRACOVIA}

(Sommario)

Dai ultimi anni XIV secolo, alla corte della santa regina Hedvige, si possono trovare le radici degli studi sui Padri nel nostro ambiente. Ma la storia della patrologia è collegata con la storia dell'Accademia di Cracovia. Nel principio gli studi patristici erano inseriti negli studi di filologia e di storia della Chiesa. Il rinascimento è collegato con l'attività della scuola filologica e teologica presso l'Università Jagiellonica nel XIX secolo ed è stata coronata con la fondazione della prima cattedra di patrologia in Polonia nel 1938. Oggi l'attività patristica accademica si svolge nell'ambiente della Accademia Pontificia di Teologia. 